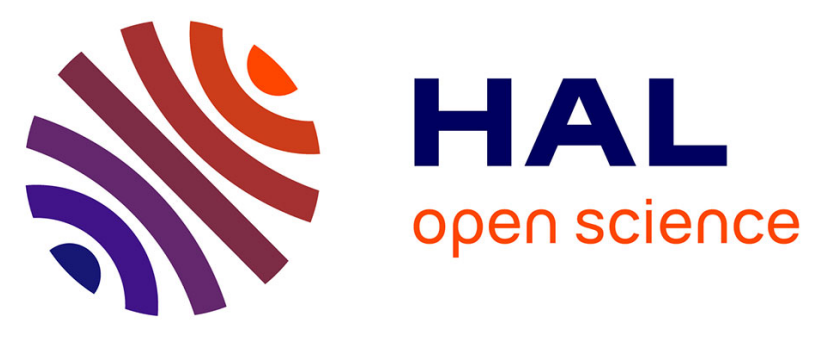

\title{
Arbutus unedo induces endothelium-dependent relaxation of the rat isolated aorta
}

Abderrahim Ziyyat, Hassane Mekhfi, Mohamed Bnouham, Abdelhafid Tahri, Abdelkhaleq Legssyer, Jacqueline Hoerter, Rodolphe Fischmeister

\section{- To cite this version:}

Abderrahim Ziyyat, Hassane Mekhfi, Mohamed Bnouham, Abdelhafid Tahri, Abdelkhaleq Legssyer, et al. Arbutus unedo induces endothelium-dependent relaxation of the rat isolated aorta. Phytotherapy Research, 2002, 16 (6), pp.572-575. 10.1002/ptr.1143 . hal-03161434

\section{HAL Id: hal-03161434 \\ https://hal.science/hal-03161434}

Submitted on 6 Mar 2021

HAL is a multi-disciplinary open access archive for the deposit and dissemination of scientific research documents, whether they are published or not. The documents may come from teaching and research institutions in France or abroad, or from public or private research centers.
L'archive ouverte pluridisciplinaire HAL, est destinée au dépôt et à la diffusion de documents scientifiques de niveau recherche, publiés ou non, émanant des établissements d'enseignement et de recherche français ou étrangers, des laboratoires publics ou privés. 


\title{
Arbutus unedo Induces Endothelium-Dependent
}

\section{Relaxation of the Rat Isolated Aorta}

\author{
Abderrahim ZIYYAT ${ }^{\mathbf{1}}$, Hassane MEKHFI ${ }^{1}$, Mohamed BNOUHAM ${ }^{\mathbf{1}}$, \\ Abdelhafid TAHRI ${ }^{1}$, Abdelkhaleq LEGSSYER ${ }^{1}$, Jacqueline \\ HOERTER $^{2}$ and Rodolphe FISCHMEISTER ${ }^{2}$
}

${ }^{1}$ Laboratoire de Physiologie et Pharmacologie Cellulaire, Département de Biologie, Faculté des Sciences, Université Mohamed Premier, BP 524, Route Sidi Maafa, 60000 Oujda Maroc.

${ }^{2}$ Laboratoire de Cardiologie Cellulaire et Moléculaire, INSERM U446, Université Paris-Sud, Faculté de Pharmacie, 5 rue Jean-Baptiste Clément F92296 Châtenay-Malabry Cedex France

Author of correspondence :

Dr. Abderrahim ZIYYAT

Laboratoire de Physiologie et Pharmacologie Cellulaire

Département de Biologie - Faculté des Sciences

Université Mohamed Premier

B.P. 524, Route Sidi Maâfa, 60000 Oujda, Morocco

Fax : +21256500603

Email : ziyyat@sciences.univ-oujda.ac.ma 


\begin{abstract}
Arbutus unedo L. (Ericaceae) is used in oriental Morocco to treat arterial hypertension. We studied its vasodilator effect and mechanisms of action in vitro. The root aqueous extract of Arbutus $(0.25 \mathrm{mg} / \mathrm{ml})$ produces a relaxation of noradrenalineprecontracted ring preparations of rat aorta with intact endothelium. Relaxation by Arbutus did not occur in specimens without endothelium and was inhibited by pretreatment with $100 \mu \mathrm{M} \mathrm{N} \mathrm{G}^{\mathrm{G}}$-methyl-L-arginine (L-NMA), $10 \mu \mathrm{M}$ methylene blue or $50 \mu \mathrm{M} 1 \mathrm{H}-[1,2,4]$ oxadiazolo [4,3-a] quinoxaline-1-one (ODQ) but not by $10 \mu \mathrm{M}$ atropine. These results suggest that Arbutus produces an endothelium-dependent relaxation of the isolated rat aorta which may be mediated mainly by a stimulation of the endothelial nitric oxide synthase by mechanisms other than activation of muscarinic receptors.
\end{abstract}

Key words : - Arbutus unedo - Ericaceae - aorta - vasorelaxation - endothelium endothelial nitric oxide synthase - NO-sensitive guanylyl cyclase

Running title: Arbutus relaxes the isolated rat aorta 


\section{INTRODUCTION}

Arbutus unedo L. is an Ericaceae species that is known in folk medicine as astringent, diuretic and urinary antiseptic (Grieve, 1967). Phytochemical studies on this plant have lead to the isolation of several products (see Karikas \& Giannitsaros, 1990). However, very little information is available about the pharmacological actions of Arbutus. Our previous survey carried out in oriental Morocco has shown that Arbutus is one of the most commonly used plants in this region to treat arterial hypertension (Ziyyat et al., 1997). In the spontaneously hypertensive rat (SHR), oral administration of the root aqueous extract of Arbutus has shown vascular, diuretic and natriuretic effects (Ziyyat \& Boussairi, 1998). The aim of this work was to examine the vascular effect of Arbutus on the isolated rat aorta and to investigate its mechanism of action.

\section{MATERIALS AND METHODS}

Plant extract preparation. The extract was prepared by decoction of $40 \mathrm{~g}$ of roots in 31 of distilled water for 2 hours (see Ziyyat \& Boussairi, 1998).

Preparation of aorta and experimental device. Male Wistar rats weighing 250-300 g were anaesthetised with sodium pentobarbital (50 mg/kg of body weight, i.p.), and the thoracic aorta was removed carefully in cold physiological salt solution (PSS). After the removal of adhering fatty and connective tissues, an aortic ring of about $2-3 \mathrm{~mm}$ in length was suspended between two stainless steel hooks in 10-ml water-jacketed bath containing PSS of the following composition (mM): $\mathrm{NaCl} \mathrm{119,} \mathrm{KCl} 4.7, \mathrm{CaCl}_{2}$ 1.6, $\mathrm{MgSO}_{4} 1.2, \mathrm{KH}_{2} \mathrm{PO}_{4} 1.2, \mathrm{NaHCO}_{3} 25$ and glucose 11. The tissue bath solution with $\mathrm{pH}$ 7.4 was maintained at $37^{\circ} \mathrm{C}$ and gassed with $95 \% \mathrm{O}_{2}+5 \% \mathrm{CO}_{2}$. The isometric contraction was recorded via a force-displacement transducer connected to an amplifier and a paper recorder. A tension of $1 \mathrm{~g}$ was initially applied to the ring which was 
equilibrated in the medium for $30 \mathrm{~min}$. Before each experiment, vasoconstriction was initiated by $1 \mu \mathrm{M}$ noradrenaline (N-Adr) in normal PSS and when the steady contraction was reached, $100 \mu \mathrm{M}$ carbachol (CCh, a cholinesterase-resistant analogue of acetylcholine) was added to induce endothelium-dependent relaxation. This step was necessary to verify the endothelium integrity. When the relaxation induced by $\mathrm{CCh}$ was $<50 \%$ the experiment was interrupted and another ring was mounted. In denuded aorta, the endothelium was removed mechanically by rubbing the lumen of the artery with plastic tubing. The absence of $\mathrm{CCh}-$ induced relaxation was taken as an indicator of successful endothelium denudation.

\section{Experimental protocols}

Protocol 1 : Vasorelaxant effect of Arbutus extract on intact aorta. Twenty minutes after the $\mathrm{N}-\mathrm{Adr} / \mathrm{CCh}$ step, contraction of aorta was obtained with $1 \mu \mathrm{M} \mathrm{N}$-Adr, after which $0.25 \mathrm{mg} / \mathrm{ml}$ of the root aqueous extract of Arbutus (AE) was added in the bath to examine its action. Then, the organ bath was rinsed two times with fresh PSS and the same protocol was repeated after pre-treatment of the ring with $10 \mu \mathrm{M}$ atropine (ATR, an inhibitor of muscarinic receptors), $100 \mu \mathrm{M} \mathrm{N} \mathrm{N}^{\mathrm{G}}$-methyl-L-arginine (L-NMA, an inhibitor of NO synthase), $10 \mu \mathrm{M}$ methylene blue (MB, a non-selective inhibitor of soluble guanylyl cyclase and/or NO synthase, see e.g. Mayer et al., 1993) or $50 \mu \mathrm{M} 1 \mathrm{H}-$ $[1,2,4]$ oxadiazolo [4,3-a] quinoxaline-1-one (ODQ, a specific inhibitor of the soluble guanylyl cyclase, see Garthwaite et al., 1995). When the action of Arbutus was blocked, $1 \mu \mathrm{M}$ sodium nitroprusside ( $\mathrm{SNP}$, an NO-donor) was added in the bath to produce an endothelium-independent relaxation.

Protocol 2 : Effect of Arbutus extract on denuded aorta. After contraction of aorta with $1 \mu \mathrm{M}$ N-Adr, vascular effects of CCh and Arbutus were tested without rinsing the bath 
after each drug. Finally, $1 \mu \mathrm{M}$ SNP was added to produce endothelium-independent relaxation.

Chemicals. The following drugs : (-)-Norepinephrine hydrochloride (Noradrenaline), $\mathrm{N}^{\mathrm{G}}$-methyl-L-arginine (L-NMA), Carbamylcholine chloride (Carbachol) were purchased from Sigma Chemical, Atropine from Labosi, Methylene blue from Grraw, Sodium nitroprusside from Farco Chemical and ODQ from Alexis Biochemicals. All compounds were dissolved in saline except ODQ which was dissolved in DMSO.

Statistics. Results are expressed as the means \pm SEM for $n$ separate experiments. Data were analysed by Student's $t$-test and a difference was considered as statistically significant when $p$ value was less than 0.05 .

\section{RESULTS}

Noradrenaline (N-Adr) induced a contraction of intact rat isolated aorta which developed a tension of $0.63 \pm 0.03 \mathrm{~g}$ (mean \pm s.e.m., $\mathrm{n}=20$ ) in the presence of $1 \mu \mathrm{M}$ of the $\alpha$-adrenergic agonist (Fig. 1a). Carbachol (CCh, $100 \mu \mathrm{M})$ produced a strong relaxant effect in the presence of $\mathrm{N}$-Adr reducing the $\alpha$-adrenergic contraction by $75 \pm 3 \%$ (Fig. 1a and Table 1). As shown in Fig. 1a, the root aqueous extract of Arbutus (AE, $0.25 \mathrm{mg} / \mathrm{ml}$ ) produced a similar relaxing effect as $\mathrm{CCh}$ on intact $\mathrm{N}$-Adrprecontracted aorta ( $77 \pm 4 \%$ reduction of contraction, Table 1$)$. However, as shown in Fig. 1b, both vasorelaxant actions of $\mathrm{CCh}$ and Arbutus disappeared completely when the endothelium was destroyed $(n=6)$ and the aorta remained contracted. To verify that removal of the endothelium did not damage the vascular muscle underneath, the aorta was challenged with the NO-donor SNP. As shown in Fig. 1b, SNP $(1 \mu \mathrm{M})$ still relaxed the endothelium-denuded aorta (on average by $75 \pm 13 \%, \mathrm{n}=4$ ). 
The above results indicate that Arbutus produces an endothelium-dependent vasorelaxation similar to that produced by $\mathrm{CCh}$. To examine whether activation of muscarinic receptors was involved in the effect or Arbutus, the vasorelaxant effect of Arbutus was re-examined in the presence of the muscarinic receptor antagonist atropine. As shown in Fig. 2a (summary data in Table 1), atropine (ATR, $10 \mu \mathrm{M}$ ) did not modify the relaxant effect of Arbutus while it completely antagonized that of CCh. However, the vasorelaxant effect of Arbutus was strongly inhibited in the presence of $100 \mu \mathrm{M}$ of the arginine analogue L-NMA (only $11 \pm 2 \%$ relaxation, $n=12$, Fig. $2 b$ and Table 1 ) indicating the participation of NO synthesis in this effect. Moreover, the vasorelaxant effect of Arbutus was completely blunted in the presence of methylene blue (MB, 10 $\mu \mathrm{M}$, Fig. 2c) or ODQ (50 $\mu \mathrm{M}$, Fig. 2d) suggesting the involvement of cGMP synthesis in this effect. It should be noted that the endothelium-independent vasorelaxant effect of NO was still preserved in the presence of either L-NMA or MB, since $1 \mu \mathrm{M}$ SNP still produced a strong relaxation of $\mathrm{N}$-Adr-precontracted aorta in the presence of $100 \mu \mathrm{M} \mathrm{L}$ NMA (84 $\pm 5 \%$ relaxation, $n=4)$ or $10 \mu \mathrm{M}$ MB $(87 \pm 3 \%$ relaxation, $n=5)$. However, the action of SNP was blocked by $50 \mu \mathrm{M}$ ODQ (only $3 \pm 2 \%$ relaxation, $\mathrm{n}=6$ ) as expected if NO-dependent relaxation is mediated by cGMP. Table 1 summarises the vasorelaxant effects of Arbutus in the absence or presence of the different drugs tested.

\section{DISCUSSION}

In the present study, we showed that an aqueous extract prepared from the roots of Arbutus produced a relaxation of precontracted aorta. At $0.25 \mathrm{mg} / \mathrm{ml}$, this effect was comparable to that produced by $100 \mu \mathrm{M}$ carbachol. Similar to the effect of CCh (see e.g. Knowles \& Moncada, 1992), the vasorelaxant effect of Arbutus disappeared in 
denuded aorta, indicating that the integrity of the endothelium was required in order for Arbutus to produce its effect. Moreover, inhibition of NO-synthase by L-NMA or inhibition of soluble guanylyl cyclase by ODQ, which both block the vasorelaxant effect of CCh (see e.g. Lucas et al., 2000), also antagonized the vasorelaxant effect of Arbutus. Although the effect of Arbutus was similar to that of $\mathrm{CCh}$, it was not due to activation of muscarinic receptors since the relaxant effect of Arbutus was unaffected by atropine. We conclude that Arbutus produces an endothelium-dependent relaxation of the aorta which involves activation of endothelial NO-synthase and subsequent cGMP synthesis in the vascular myocytes but does not involve activation of muscarinic receptors.

Interestingly, both the vasorelaxant effects of Arbutus and CCh were blocked by methylene blue which is classically used as an inhibitor of soluble guanylyl cyclase (see e.g. Moncada et al., 1991). However, this compound should be used with caution since it exerts a number of other effects including inhibition of muscarinic receptors (AbiGerges et al., 1997) and inhibition of NO-synthase (Mayer et al., 1993). As such, we found here that methylene blue inhibited the effect of $\mathrm{CCh}$ on $\mathrm{N}$-Adr-precontracted aorta but left unchanged the relaxant effect of the NO-donor SNP. Therefore, we interpret our results with methylene blue as an effect due to inhibition of NO-synthase rather than inhibition of guanylyl cyclase.

The endothelium-dependent vasodilator effects of Arbutus could be attributed to a number of polyphenolic compounds likely present in the extract. These include tannins and flavonoids which are known for their cardiovascular effects (Fitzpatrick et al., 1993; 1995; Andriambeloson et al., 1998, 1999; Middleton et al., 2000). For example, quercitin (a flavonoid) and tannic acid (a tannin) produce endothelium-dependent 
relaxation of rat aortic rings (Fitzpatrick et al., 1993, Flesch et al., 1998) and human coronary arteries and increase cGMP content in both preparations (Flesch et al., 1998). Arbutus roots were shown to contain tannins (Garnier et al., 1961) and aerial parts to contain flavonoids (Dauguet \& Foucher, 1982). According to a preliminary phytochemical analysis performed in collaboration with Drs H. Allali and B. Tabti (Laboratory of Organic Chemistry of Tlemcen University , Algeria), both flavonoids and tannins are abundant in the roots of Arbutus (unpublished data). Work is in progress to isolate these compounds, to show their vascular effects in vitro and to identify the active principle(s) responsible of the endothelium-dependent vasorelaxation induced by Arbutus.

In conclusion, we showed in this study that Arbutus produces an endotheliumdependent relaxation of aorta which is mainly mediated by a stimulation of endothelial nitric-oxide synthase. We speculate that this effect accounts for the utilisation of Arbutus in folk medicine for the treatment of arterial hypertension.

\section{Acknowledgements}

We gratefully acknowledge Dr Renée Ventura-Clapier and Mr. Patrick Lechêne (Laboratoire de Cardiologie Cellulaire et Moléculaire, INSERM Unité 446, ChâtenayMalabry, Université Paris Sud, France) and Pr. Driss Moussaid (Laboratoire d'Electronique et Systèmes, Faculté des Sciences, Oujda, Maroc) for their precious help. We also thank Drs Houcine Allali and Boufeldja Tabti (Laboratoire de Chimie Organique, Université de Tlemcen, Algérie) for chemical analysis, and Pr. Benyounès Haloui from our Department for Botanical Determination. This work was supported by grants from The Centre National de Recherche du Maroc (Projet PARS médecine 081, Maroc) and from INSERM (Projet Franco-Marocain INSERM-CNCPRST). 


\section{REFERENCES}

Abi-Gerges, N., Eschenhagen, T., Hove-Madsen, L., Fischmeister, R., and Méry, P. F. (1997). Methylene blue is a muscarinic antagonist in cardiac myocytes. Mol. Pharmacol. 52, 482-490.

Andriambeloson, E., Magnier, C., Haan-Archipoff, G., Lobstein, A., Anton, R., Beretz, A., Stoclet, J. C., and Andriantsitohaina, R. (1998). Natural dietary polyphenolic compounds cause endothelium-dependent vasorelaxation in rat thoracic aorta. $J$. Nutr. 128 (12), 2324-2333.

Andriambeloson, E., Stoclet, J. C., and Andriantsitohaina, R. (1999). Mechanism of endothelial nitric oxide-dependent vasorelaxation induced by wine polyphenols in rat thoracic aorta. J. Cardiovasc. Pharmacol. 33 (2), 248-254.

Dauguet, J. C., and Foucher, J. P. (1982). Les flavonoïdes de Arbutus unedo L. (Ericacées). Plant. Med. Phytotherap. XVI 3, 185-191.

Fitzpatrick, D. F., Hirschfield, S. L., and Coffey, R. G. (1993). Endothelium-dependent vasorelaxing activity of wine and other grape products. Am. J. Physiol. 265, H774H778.

Fitzpatrick, D. F., Hirschfield, S. L., Ricci, T., Jantzen, P., and Coffey, R. G. (1995). Endothelium-dependent vasorelaxation caused by various plant extracts. $J$. Cardiovasc. Res. 26, 90-95.

Flesch, M., Schwarz, A., and Bohm, M. (1998). Effects of red and white wine on endothelium-dependent vasorelaxation of rat aorta and human coronary arteries. Am. J. Physiol. 275, H1183-H1190.

Garnier, G., Bezanger-Beauquesne, L., and Debraux, G. (1961). Ressources Médicinales de la Flore Française, Vol. 2, pp. 962-964, Vigot Frères, Paris.

Garthwaite, J., Southam, E., Boulton, C. L., Nielson, E. B., Schmidt, K., and Mayer, B. (1995). Potent and selective inhibition of nitric oxide-sensitive guanylyl cyclase by 1-H-[1,2,4]oxadiazolo[4,3-a]quinoxalin-1-one. Mol. Pharmacol. 48, 184-188. 
Grieve, M. (1967). A Modern Herbal. Vol. 1, p. 53, Hafner Publishing Co., New York and London.

Karikas, G. A., and Giannitsaros, A. (1990). Glucosides phénoliques des feuilles d'Arbutus unedo. Plant. Med. Phytother. XXIV 1, 27-30.

Knowles, R. G., and Moncada, S. (1992). Nitric Oxide as a Signal in Blood Vessels. Trends Biochem. Sci. 17, 399-402.

Lucas, K. A., Pitari, G. M., Kazerounian, S., RuizStewart, I., Park, J., Schulz, S., Chepenik, K. P., and Waldman, S. A. (2000). Guanylyl cyclases and signaling by cyclic GMP. Pharmacol. Rev. 52, 375-413.

Mayer, B., Brunner, F., and Schmidt, K. (1993) Inhibition of nitric oxide synthesis by methylene blue. Biochem. Pharmacol. 45, 367-374.

Middleton, E. Jr, Kandaswami, C., and Theoharides, T. C. (2000). The effects of plant flavonoids on mammalian cells: implication for inflammation, heart disease, and cancer. Pharmacol. Rev. 52, 637-751.

Moncada, S., Palmer, R. M. J., and Higgs, E. A. (1991). Nitric Oxide - Physiology, Pathophysiology, and Pharmacology. Pharmacol. Rev. 43, 109-142.

Ziyyat, A. Legssyer, A., Mekhfi, H., Dassouli, A., Serhrouchni, M., and Benjelloun, W. (1997). Phytotherapy of hypertension and diabetes in oriental Morocco. $J$. Ethnopharmacol. 58, 45-54.

Ziyyat, A., and Boussairi, E. (1998). Cardiovascular effects of Arbutus unedo L. in spontaneously hypertensive rats. Phytother. Res. 12, 110-113. 


\begin{tabular}{|c|c|c|c|c|c|c|}
\hline \multicolumn{7}{|c|}{$\begin{array}{l}\text { Table 1. Mean values of the vasorelaxant effect } \\
\text { intact noradrenaline-precontracted ao } \\
\text { extract (AE) of Arbutus unedo in absen } \\
\text { methylene blue (MB) or ODQ. }\end{array}$} \\
\hline \multirow{3}{*}{\multicolumn{2}{|c|}{$\begin{array}{c}\mathrm{CCh} \\
100 \mu \mathrm{M}\end{array}$}} & \multicolumn{5}{|c|}{$\mathrm{AE} 0.25 \mathrm{~g} / 1$} \\
\hline & & \multirow[t]{2}{*}{ AE alone } & \multirow{2}{*}{$\begin{array}{c}+ \text { Atropine } \\
10 \mu \mathrm{M}\end{array}$} & \multirow{2}{*}{$\begin{array}{c}+ \text { L-NMA } \\
100 \mu \mathrm{M}\end{array}$} & \multirow{2}{*}{$\begin{array}{l}+\mathrm{MB} \\
10 \mu \mathrm{M}\end{array}$} & \multirow{2}{*}{$\begin{array}{l}+ \text { ODQ } \\
50 \mu \mathrm{M}\end{array}$} \\
\hline & & & & & & \\
\hline Mean & $75 \pm 3(\mathrm{NS})$ & $77 \pm 4$ & $86 \pm 4(\mathrm{NS})$ & $11 \pm 2^{a}$ & $0.4 \pm 0.4^{\mathrm{a}}$ & $0^{\mathrm{a}}$ \\
\hline $\mathrm{n}$ & 20 & 20 & 6 & 12 & 4 & 6 \\
\hline \multicolumn{7}{|c|}{$\begin{array}{l}\text { Values are mean } \pm \text { SEM. }{ }^{a} p<0.001 \text { vs AE alone ; NS : not significant compared to AE } \\
\text { alone. }\end{array}$} \\
\hline
\end{tabular}




\section{Legend of figures}

\section{Figure 1}

Typical tracings showing the effect of carbachol $(\mathrm{CCh}, 100 \mu \mathrm{M})$ and root aqueous extract of Arbutus $(\mathrm{AE}, 0.25 \mathrm{mg} / \mathrm{ml})$ on noradrenaline $(\mathrm{N}$-Adr, $1 \mu \mathrm{M})$ pre-contracted intact (a) and denuded rat aorta (b). Sodium nitroprusside (SNP, $1 \mu \mathrm{M}$ ) was added to produce an endothelium-independent relaxation. W indicates the moment when all drugs were washed out.

\section{Figure 2}

Original tracings showing the vascular effect of carbachol $(\mathrm{CCh}, 100 \mu \mathrm{M})$ and aqueous extract of Arbutus (AE, $0.25 \mathrm{mg} / \mathrm{ml})$ on noradrenaline $(\mathrm{N}$-Adr, $1 \mu \mathrm{M})$ pre-contracted intact rat aorta in presence of : (a) atropine (ATR, $10 \mu \mathrm{M}$ ); (b) $\mathrm{N}^{\mathrm{G}}$-methyl-L-arginine (L-NMA, $100 \mu \mathrm{M}$ ); (c) methylene blue (MB, $10 \mu \mathrm{M}$ ); or (d) ODQ $50 \mu \mathrm{M}$. Endothelium-independent relaxation was obtained with sodium nitroprusside (SNP, 1 $\mu \mathrm{M}) . \mathrm{W}$ indicates the moment when all drugs were washed out. 
$\mathbf{a}$
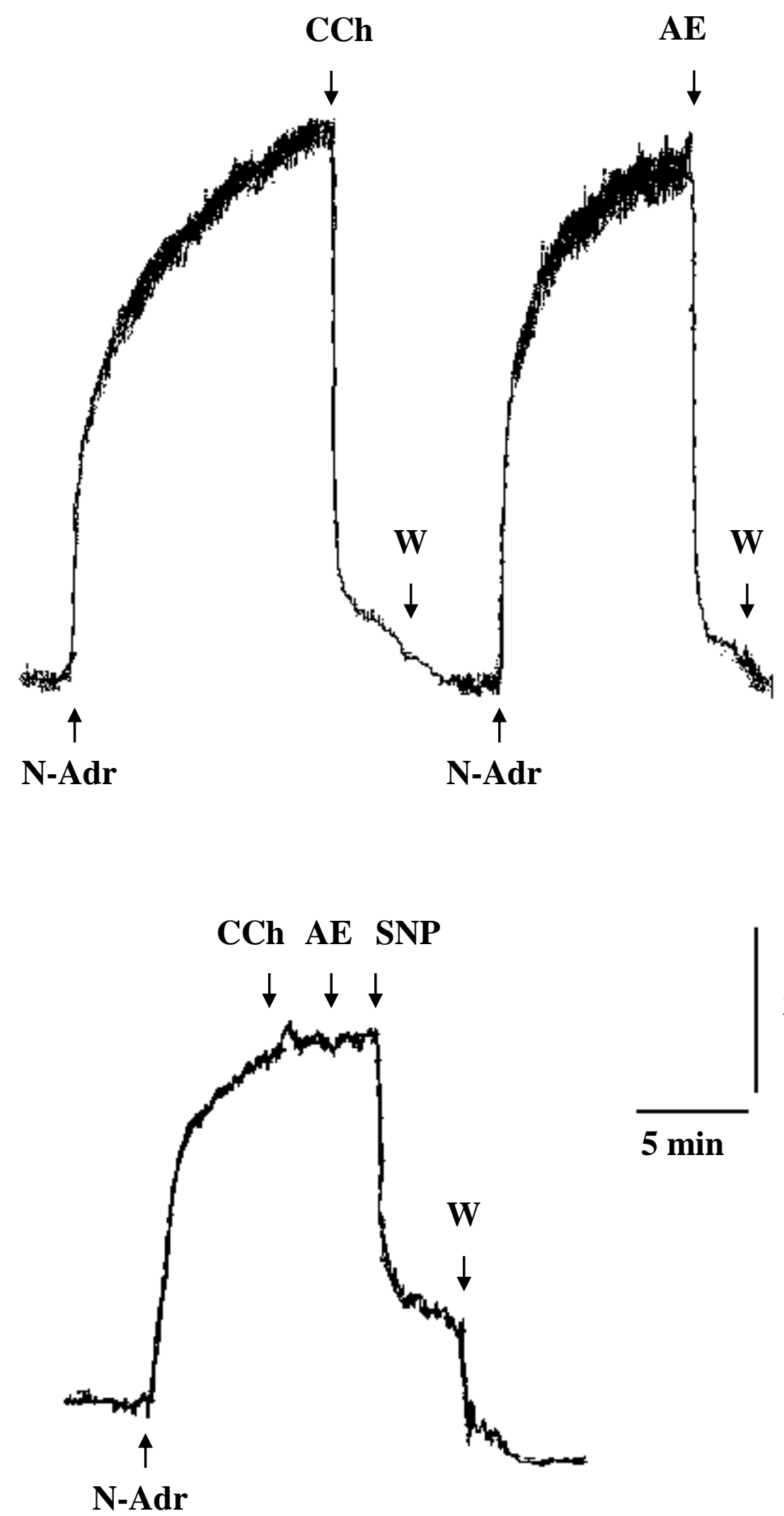


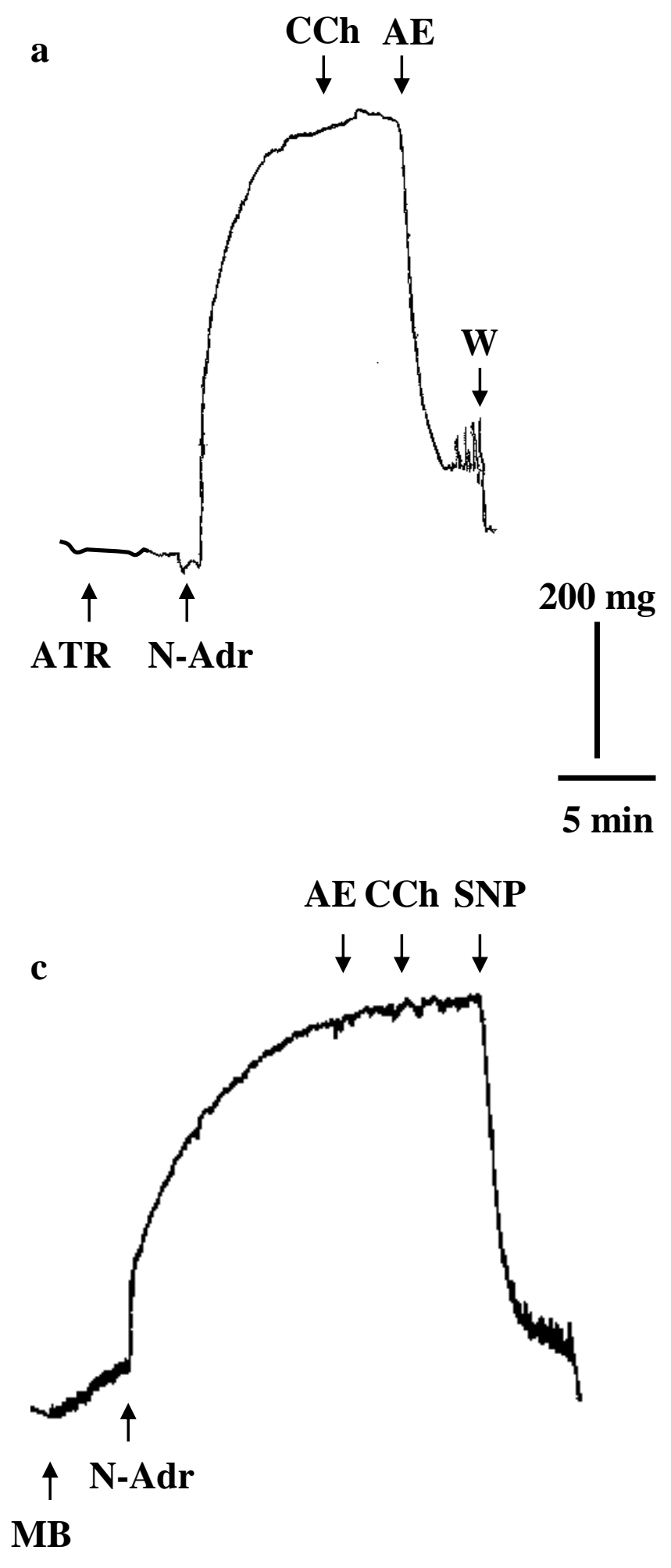

b

AE SNP

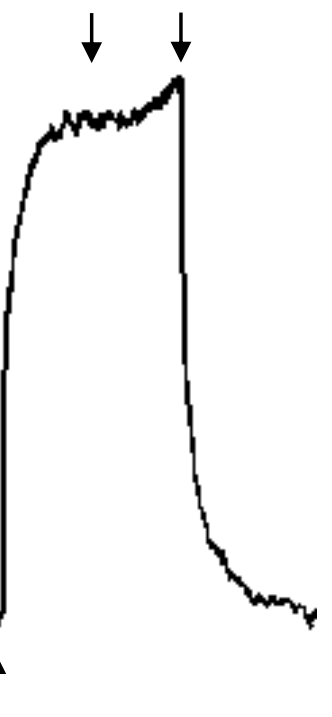

L-NMA N-Adr

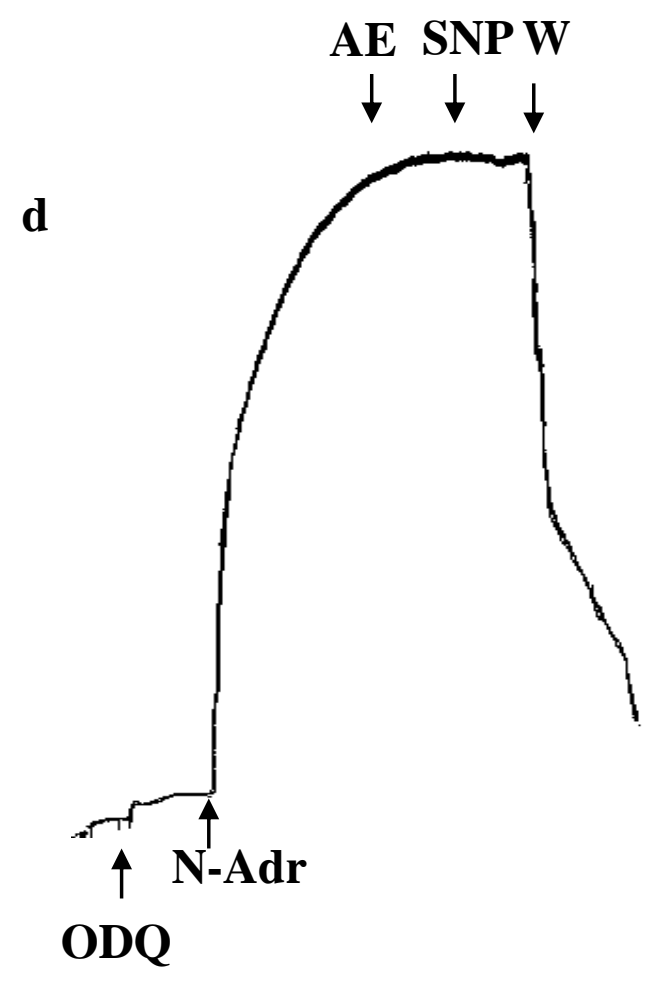

